\title{
NOTE
}

\section{COMPETITORS' STANDING TO CHALLENGE ADMINSTRATIVE ACTION UNDER THE APA}

Prior to the passage of the Administrative Procedure Act, ${ }^{1}$ the law governing a competitor's standing to challenge administrative action was in a confused state. ${ }^{2}$ The enactment of section 10(a) of the APA $^{3}$ has compounded the uncertainty since it is not clear whether prior law, whatever its content, was codified or changed. This problem of competitors' standing will be considered in three contexts: in the absence of a statutory provision for appeal by aggrieved persons, appeal under such statutes, and under section 10(a) of the Administrative Procedure Act.

\section{Competitors' Standing Absent An “Aggrieved Person” Provision}

In the absence of statutory authorization for judicial review of administrative action by "aggrieved" or "adversely affected" persons, standing to challenge governmental action must be based upon injury to a legally protected interest. ${ }^{4}$ A series of Supreme Court cases in the 1930's established that a commercial enterprise which does not hold an exclusive franchise has no "right" to be free from unauthorized federal action if the only detrimental effect upon it is injury incident to increased competition. In Alabania Power Co. v. Ickes ${ }^{5}$ and Duke Power Co. v. Greenzood County, ${ }^{\circ}$ the suits of private power companies contesting federal authority to finance the construction of competing municipal power facilities were dismissed. Since state law authorized municipalities to engage in the power business, plaintiffs were injured merely by lawful competition. Again, in Tennessee Electric Pozer Co. v. TVA, the plaintiffs were held to have no standing to challenge federal authority to compete with them through TVA because plaintiffs' injury merely resulted from increased competition. The rule

1. 60 Stat. 237 (1946), 5 U.S.C. $\$ \S 1001-11$ (1952).

2. For the role of judicial review in the administrative process, see ATT'y GEN. Comm. on Administrative Procedure, Report 76-79 (1941).

3. 60 STAT. 243 (1946), 5 U.S.C. $\$ 1009$ (a) (1952).

4. Frothingham v. Mellon, 262 U.S. 447, 488 (1923). Considerations of the separation of governmental powers as well as the constitutional mandate of "case" or "controversy" require that the constitutionality of governmental acts is to be determined only as an incident to the judicial function of redressing injury. Therefore, the litigant not only must show injury as a result of unlawful government action but also that his injured interest is one which the courts will protect. Ibid. Prediction of what will be a sufficient showing of legal injury for purposes of standing may be difficult since the usual judicial explanation for denial of standing is the circular statement that no legal injury is shown. For an attempt to indicate factors relevant to this determination, see Joint Anti-Fascist Refugee Committee v. McGrath, 341 U.S. 123, 149-57 (1951) (concurring opinion of Justice Frankfurter).

5. 302 U.S. 464 (1938).

6. 302 U.S. 485 (1938). (1929).

7. 306 U.S. 118 (1939). Contra, Frost v. Corporation Comm'n, 278 U.S. 515 
of these cases still is so well established ${ }^{8}$ that there have been relatively few suits attempting to meet the "legal injury" requirement by basing standing solely on competitive injury. ${ }^{9}$

However, in recent competitor cases, some attempt has been made to modify the scope of the "legal injury" rule.10 This succeeded in Atchison T. ES S.F. Ry. v. Summerfield, ${ }^{11}$ where a railroad was permitted to challenge a Post Office decision to utilize air rather than rail carriage. Standing was permitted on the theory that the railroad had sufficient interest in that it had been obligated to provide and maintain facilities for mail carriage. Although the rule that competitive injury in itself is insufficient basis for standing absent a statute was not rejected, the case suggests a possible more liberal attitude toward competitors' standing when official action in granting subsidies is involved. ${ }^{12}$

\section{Competitors" Standing Under the “Aggrieved Person" Statutes General}

Most cases involving competitors' standing arise under statutory standing provisions enacted prior to the APA. Congress avoided the "legal injury" rule by providing in several statutes that "aggrieved persons" have a right to challenge administrative action. Actually, this identifying phrase is not the same in all of the statutes; its basic variants are "aggrieved person," 13 person "adversely affected," 14 and "any party in inter-

8. See Kansas City Power \& Light Co. v. McKay, 225 F.2d 924 (D.C. Cir.), cert. denied, 350 U.S. 884 (1955); United Milk Producers v. Benson, 225 F.2d 527 (D.C. Cir. 1955) ; Atchison T. \& S.F. Ry. v. United States, 130 F. Supp. 76 (E.D. Mo.) (alternative holding), aff'd per curiam, 350 U.S. 892 (1955).

9. See Atlantic Freight Lines, Inc. v. Summerfield, 204 F.2d 64 (D.C. Cir. 1952), cert. denied, 346 U.S. 828 (1953) (motor carrier has no standing to enjoin issuance of commemorative postage stamp honoring competing railroad); compare Friend v. Lee, 221 F.2d 96 (D.C. Cir. 1955) (unsuccessful bidder for airport concession has no standing to assert CAB's non-compliance with statutory bid procedure), with McKay v. Wahlenmaier, 226 F.2d 35 (D.C. Cir. 1955) (unsuccessful bidder was permitted to challenge grant of mineral lease to a bidder known to have violated applicable regulations without any discussion of standing); cf. Chapman v. Sheridan-Wyoming Coal Co., 338 U.S. 621 (1950) (suit challenged federal action favorable to a competitor on the ground it violated applicable regulations; appellant attempted to base standing on injury to a contractual right by asserting the allegedly violated regulations impliedly were incorporated into his federal coal lease).

10. Kansas City Power \& Light Co. v. McKay, 225 F.2d 924 (D.C. Cir.), cert. denied, 350 U.S. 884 (1955) (attempt to base standing on allegations of official conspiracy rejected). See also Chapman v. Sheridan-Wyoming Coal Co., 338 U.S. 621 (1950), and notes 11 and 12 infra.

11. 229 F.2d 777 (D.C. Cir. 1955).

12. For a discussion of the need for judicial review of subsidy grants and standing developments in this area, see Eisenberg, Judicial Standing in Subsidy Cases: Availability of Review Should Be Expanded, 41 A.B.A.J. 718 (1955).

13. Securities Act of 1933, 48 STAT. 80, 15 U.S.C. \$77i(a) (1952); Public Utility Holding Company Act, 49 STAT. 834 (1935), 15 U.S.C. \& 79x(a) (1952); Federal Power Act, 49 STAT. 860 (1935), 16 U.S.C. $\$ 825 l$ (b) (1952); Federal Communications Act, 48 STAT. 926 (1934), 47 U.S.C. $\$ 402$ (b) (1952). Some statutes extend such standing only to an "aggrieved party." See, e.g., Securities Exchange Act, 48 Stat. 901 (1934), 15 U.S.C. \& 78y(a) (1952); Natural Gas Act, 52 Stat. 831 (1938), 15 U.S.C. \& $717 \mathrm{r}$ (b) (1952).

14. Federal Food, Drug and Cosmetic Act, 52 STAT. 1055 (1938), 21 U.S.C. § 371(f) (1952); Federal Communications Act, 48 STAT. 926 (1934), 47 U.S.C. $\S 402(\mathrm{~b})(1952)$. 
est." 1s Since congressional choice of these different terms seems to have been fortuitous and the courts have not interpreted them to have intrinsically different meanings, ${ }^{10}$ it is convenient to refer to them collectively in this section as "aggrieved person" provisions.

Under these provisions, the litigant must show detriment to obtain standing; however, his own injury need not be a "legal injury" or related to the substantive issues which will be raised. ${ }^{17}$ For example, the Federal Communications Act ${ }^{18}$ does not protect radio stations from loss of revenue due to the licensing of competing stations. This financial detriment is significant only in that it may qualify the radio stations to appeal the action; the substantive case against the administrator must be based on other grounds. ${ }^{10}$

\section{Judicial Interpretation of the "Aggrieved Person" Standard}

The statutory limitation on the number of appeals, expressed by the "aggrieved" requirement, probably derives from the belief that litigants who do not have a personal interest in the outcome of the litigation would not meet the constitutional "case" or "controversy" requirement. ${ }^{20}$ The courts have regarded the injury that would satisfy this constitutional requirement of adverse effect as insufficient to sustain standing under the "aggrieved person" statutes, on the belief that administrative policies require a more restrictive approach to standing. A liberal application of statutory standing might result in a flood of suits and appeals, thereby interfering with effective administrative action, ${ }^{21}$ or might "clog" the ad-

15. Interstate Commerce Act, 24 STaT. 379 (1887), 49 U.S.C. \& 1(20) (1952) ("party in interest") ; cf. Civil Aeronautics Act, 52 STAT. 1024 (1938), 49 U.S.C. $\$ 646$ (a) (1952) ("a substantial interest").

16. Davis, Standing To Challenge Governmental Action, 39 MINN. L. Rev. 353, 359 \& n.30 (1955). But see Federal Food, Drug and Cosmetic Act, 52 Stat. 1055 (1938), 21 U.S.C. $\$ \$ 371(\mathrm{e})$, (f) (1952) "Any interested person" may participate in the agency proceeding but a right of appeal is granted to any person who will be "adversely affected."); Federal Communications Act, 48 STar. 926 (1934), 47 U.S.C. \$402(b) (1952) (both "aggrieved" and "adversely affected" persons may appeal).

17. See, e.g., FCC v. Sanders Bros. Radio Station, 309 U.S. 470, $475-77$ (1940); Pittsburgh v. FPC, 24 U.S.L. WeEK 2418, 2419 (D.C. Cir. March 8, 1956).

18. 48 Stat. 1064 (1934), as amended, 47 U.S.C. $\S \S 15-609$ (1952).

19. FCC v. Sanders Bros. Radio Station, 309 U.S. 470 (1940). The factor of competition between the applicant and existing licensees is relevant to whether the license should issue only where destructive competition between them may deprive the public of any effective service. Ibid.

20. U.S. CoNST. art. III, \&2. Since the "legal injury" requirement of standing is derived from conceptions of the proper relation of the federal courts to the executive and legislative branches, see note 4 supra, no constitutional problem is presented when Congress provides that less deference is to be accorded to administrative acts. However, the Supreme Court has not retreated from its position in Frothingham v. Mellon, 262 U.S. 447 (1923), that the litigant must have a personal interest in the outcome of the dispute. See, e.g., Joint Anti-Fascist Refugee Committee v. McGrath, 341 U.S. 123, 151 (1951) (concurring opinion); FCC v. National Broadcasting Co., 319 U.S. 239, 265 (1943) (dissenting opinion).

21. See, e.g., United States Cane Sugar Refiners' Ass'n v. McNutt, 138 F.2d 116, 120 (2d Cir. 1943). But see Associated Industries, Inc. v. Ickes, 134 F.2d 694, 707 (2d Cir.), dismissed as moot, 320 U.S. 707 (1943). 
ministrative process since litigation of an agency decision may deprive it of practical effect for a substantial period of time. ${ }^{22}$ It is also possible that persons who will fully and diligently contest the disputed action best promote the public interest in correcting administrative error by providing the most effective challenge to the agency decision. While this is not expressed, it may underlie the courts' concern with the "directness" of the alleged injury. ${ }^{23}$

These policies dictate the limitation of suits and appeals by aggrieved persons and a factual study of the cases indicates that certain factors, although unarticulated, apparently have influenced the selection of litigants. ${ }^{24}$ A primary factor is whether suit or appeal by other persons will represent the position of the litigant, ${ }^{25}$ although those persons have not challenged the agency in this case. ${ }^{28}$ The severity of the potential litigant's injuries may be considered, since it is likely to be related to the diligence of his challenge. ${ }^{27}$ The importance of deciding a case on the merits, especially if it presents a novel question which has been well presented, may induce a court to permit standing. ${ }^{28}$ When the litigant is a member of a group

22. See FCC v. National Broadcasting Co., 319 U.S. 239, 260 (1943) (dissenting opinion); cf. FCC ANN. REP. 93 (1954) (protests made unnecessarily and to delay licensing of competitors). Consider, for example, the delay created by the review of one order certifying the construction of a natural gas pipe line. Final modification of the agency order was entered May 6, 1947. Michigan-Wisconsin Pipe Line Co., 6 F.P.C. 616 (1947). The circuit court affirmed on June 3, 1948. Panhandle Eastern Pipe Line Co. v. FPC, 169 F.2d 881 (D.C. Cir. 1948). Certiorari was denied October 25, 1948. Panhandle Eastern Pipe Line Co. v. FPC, 335 U.S. 854 (1948). The fact that construction is undertaken while a case is on appeal will not prevent reversal of an improper order. Cf. Northeastern Gas Transmission Co. v. FPC, 195 F.2d 872 (3d Cir.), cert. denied, 344 U.S. 818 (1952) (case remanded to FPC for further hearing on competitive application after first licensee had almost completed construction), as elucidated in Algonquin Gas Transmission Co. v. FPC, 201 F.2d 334, 336 (1st Cir. 1953). Therefore, construction probably would not be commenced pending the outcome of court review.

23. L. Singer \& Sons v. Union Pac. R.R., 311 U.S. 295, 304 (1940) ("indirect") ; United States Cane Sugar Refiners' Ass'n v. McNutt, 138 F.2d 116, 120-21 (2d Cir. 1943) ("remote"); cf. Ex-Cell-O Corp. v. Chicago, 115 F.2d 627, 631 (7th Cir. 1940) ("remote").

24. See, generally, Note, Statutory Standing To Review Administrative Action, 98 U. PA. L. REv. 70 (1949).

25. See, e.g., L. Singer \& Sons v. Union Pac. R.R., 311 U.S. 295, 305 (1940) (concurring opinion). Compare Schenley Distillers Corp. v. United States, 326 U.S. 432 (1946), with American Power \& Light Co. v. SEC, 325 U.S. 385 (1945).

26. If a litigant who shows some detriment may be the only person with sufficient interest to raise the question of administrative error, standing may be upheld. See Parker v. Fleming, 329 U.S. 531 (1947); FCC v. Sanders Bros. Radio Station, 309 U.S. 470 (1940); Pittsburgh v. FPC, 24 U.S.L. WEer 2418 (D.C. Cir. March 8, 1956) ; Clarksburg Publishing Co. v. FCC, 225 F.2d 511 (D.C. Cir. 1955); A. E. Staley Mfg. Co. v. Secretary of Agriculture, 120 F.2d 25 (7th Cir. 1941).

27. See text at note 23 supra. A belief that a personal interest in the outcome of the dispute results in stronger adversary interest and, therefore, in fuller litigation of the issues seems to be the basis for the judicial rule that "case" or "controversy" requires the litigant to show "adverse effect."

28. Compare Panhandle Eastern Pipe Line Co. v. FPC, 219 F.2d 729 (3d Cir.), cert. denied, 349 U.S. 945 (1955) (rigorous investigation of appellant's alleged injury), with Eastern Airlines, Inc. v. CAB, 185 F.2d 426 (D.C. Cir. 1950) (injury assumed to be substantial) ant A. E. Staley Mfg. Co. v. Secretary of Agriculture, 120 F.2d 258 (7th Cir. 1941) (from facts recited by court injury seems unlikely). 
whose interests the statute was designed to protect, courts may be inclined to recognize his standing. ${ }^{29}$ The manner in which these various factors may influence the determination of a particular competitor case can be illustrated by a fuller consideration of the problems of statutory standing in the context of the decided cases.

\section{Competitors' Standing As Aggrieved Persons}

Cases which involve administrative action impairing the prospective litigant's business in its competition with another present several recurring factual situations which can be divided into two major categories, the first dealing with how the injury arose and the second with who is the appellant.

\section{How Did The Injury Arise?}

\section{A New Competitor Is Lannched}

In industries where the government has undertaken to limit entry by requiring a certificate of public convenience and necessity or similar permit for newcomers, ${ }^{30}$ or agency approval for extension or expansion of an existing business, ${ }^{31}$ the administrative action results in an increase in competition for established businesses which may, therefore, wish to challenge the order.

Initially, however, the litigant must show that the administrative act will be detrimental to him; therefore, in some instances where agency certification is ordered to alleviate inadequate existing service, the litigant may not be able to show that he will be materially injured as a result of the order. In Panhandle Eastern Pipe Co. v. FPC, ${ }^{32}$ for example, appellant was a natural gas carrier, supplying a distributor in the Michigan-Wisconsin area. The Federal Power Commission had certified the construction of new lines by other carriers to meet an undersupply in that territory. One of these carriers planned to deliver gas to appellant's distributor-customer. Despite appellant's argument of injury from increased competition, standing was denied. The court found that appellant already had commitments for its full capacity and did not plan to enlarge its facilities; hence it would lose no business as a result of deliveries to presently unserved localities. Nor

See also Adler v. Board of Education, 342 U.S. 485 (1952) (case involving constitutionality of state legislation; only one Justice discusses a difficult problem of standing).

29. E.g., compare Reade v. Ewing, 205 F.2d 630 (2d Cir. 1953) (consumer had standing under Federal Food, Drug and Cosmetic Act), with L. Singer \& Sons v. Union Pac. R.R., 311 U.S. 295 (1940) (market competitor had no standing under $\S 1(20)$ of the Interstate Commerce Act).

30. See, e.g., Natural Gas Act, 52 Star. 884 (1938), 15 U.S.C. \& 717f(a) (1952); Interstate Commerce Act, 24 STAT. 383 (1887), as amended, 49 U.S.C. \$1(18) (1952); Civil Aeronautics Act of 1938, 52 Stat. 987, 49 U.S.C. $\$ 481$ (1952).

31. See, e.g., Interstate Commerce Act, 24 Stat. 383 (1887), as amended, 49 U.S.C. $\$ 1(18)$ (1952); Civil Aeronautics Act of 1938, 52 STAT. 987, 49 U.S.C. $\S 481(1952)$.

32. 219 F.2d 729 (3d Cir.), cert. denied, 349 U.S. 945 (1955). 
would it lose its existing outlet, since the distributor was under contractual obligation to receive a fixed amount of gas. ${ }^{33}$ However, where the existing business can supply service to all who request it, and its service is inadequate for other reasons, such as inconvenience, the established enterprise may have standing to challenge certification. In Claiborne-Annapolis Ferry Co. $v$. United States, ${ }^{34}$ an existing ferry company was held to have standing to appeal the certification of a new line. Here appellant's facilities, aithough adequate to meet traffic demands, were inconveniently located for many users. The new line was designed to provide more direct service for part of this area. Therefore, appellant was threatened with loss of business to the new line, and this injury was held sufficient for standing.

The necessity of proving injury seems to be the chief obstacle for litigants in this type of case. Where material detriment is shown, existing members of regulated industries, such as radio ${ }^{35}$ and natural gas, ${ }^{36}$ have been allowed to challenge certification of competitors. One court indicated that air carriers may do the same. ${ }^{37}$ Since the administrative action causes immediate economic effect to this class of litigants, it is likely that they will prosecute their suits diligently. Furthermore, such competitors often may be the only group having sufficient interest in the certification to wish to challenge it in the courts.

Similar considerations justify the standing of rail ${ }^{38}$ and motor carriers ${ }^{39}$ to challenge the certification either of new members of their respective industries or the territorial expansion of existing concerns. However, courts have stressed a different factor in sustaining their standing. The Transportation Act of $1920^{40}$ has been interpreted by the Supreme Court to derive from a congressional belief that uncontrolled competition among railroads results in weak systems and unnecessary duplication of facilities. ${ }^{\mathbf{1 1}}$ Since promotion of the public interest in transportation is closely connected with the vitality of individual carriers, it was thought that a major statutory purpose was served by allowing existing rail carriers to challenge rail

33. Cf. Panhandle Eastern Pipe Line Co. v. FPC, 169 F.2d 881 (D.C. Cir.), cert. denied, 335 U.S. 854 (1948) (no discussion of standing but here appellant would have been subjected to competition).

34. 285 U.S. 382 (1932).

35. See, e.g., FCC v. Sanders Bros. Radio Station, 309 U.S. 470 (1940).

36. Panhandle Eastern Pipe Line Co. v. FPC, 169 F.2d 881 (D.C. Cir.), cert. denied, 335 U.S. 854 (1948) (by implication); Cia Mexicana de Gas v. FPC, 167 F.2d 804 (5th Cir. 1948) ; Arkansas-Louisiana Gas Co. v. FPC, 113 F.2d 281' (5th Cir. 1940).

37. Pan American Airways Co. v. CAB, 121 F.2d 810, 813 (2d Cir. 1941).

38. See Western Pac. Calif. R.R. v. Southern Pac. Co., 284 U.S. 47 (1931); Texas \& Pac. Ry. v. Gulf, C. \& S.F. Ry., 270 U.S. 266 (1926).

39. See, e.g., Hudson Transit Lines, Inc. v. United States, 82 F. Supp. 153 (S.D.N.Y. 1948), aff'd per curiam, 338 U.S. 802 (1949) ; Lang Transp. Corp. v. United States, 75 F. Supp. 915 (S.D. Cal. 1948); Inland Motor Freight v. United States, $36 \mathrm{~F}$. Supp. 885 (D. Idaho 1941); Consolidated Freightways, Inc. v. United States, 34 F. Supp. 576 (D. Utah 1940).

40. 41 Stat. 456 (1920), 49 U.S.C. \$\$1(18)-(20) (1952).

41. See note 38 supra. 
extensions which injured them. ${ }^{42}$ For similar reasons, this doctrine subsequently was applied to appeals by motor carriers under the Motor Carrier Act. ${ }^{43}$

Under the Federal Food, Drug and Cosmetic Act,4t the Administrator is not charged with certification of the entry of new enterprises into an industry or the expansion of existing concerns into new territory. However, administrative rules issued under the act may have similar impact upon competitive relations. The Administrator, who is authorized to define standards of quality or identity for products shipped in interstate commerce, ${ }^{45}$ may redefine the standards of a product so that a previously unauthorized ingredient may be used. Manufacturers of the previously authorized ingredient face new competition and may wish to contest the validity of the rule. Although the manufacturers' status as aggrieved competitors has not been determined in this situation, ${ }^{46}$ a dictum indicates that standing might result. ${ }^{47}$

If the factors previously suggested as influencing the courts' decisions are considered, this is a justifiable result. In determining whether anyone other than this appellant could challenge the agency action, it must be recognized that the groups theoretically most likely to contest administrative action under this statute are consumers and competitors. However, in practice, consumer action does not effectively police the Administrator since individual consumers are unlikely to be sufficiently interested to spend time and money to appeal. Consumer associations also have not been active litigants under the act in cases involving these rules, possibly because they have involved little danger to consumer interests. So long as there is no danger of an unhealthful or substandard product, consumers are unlikely to appeal rules which arbitrarily favor one group of manufacturers. The only other possibility for appeal of this form of improper administration is through the medium of a competitor's complaint.

\section{Suppliers Who Are Excluded From Their Markets}

A second recurring factual situation in which action by an administrative agency affects a competitive relationship develops when the agency forecloses a supplier of goods and services from selling in a market in

42. Ibid. In Claiborne-Annapolis Ferry Co. v. United States, 285 U.S. 382 (1932), the act was interpreted to authorize parties in interest to challenge the improper grant of a certificate as well as to enjoin uncertified construction.

43. See 54 STAT. 922 (1935), 49 U.S.C. $\$ 305(\mathrm{~g})(1952)$, and cases cited in note 39 supra.

44. 52 STAT. 1040 (1938), 21 U.S.C. $\S \S 301-92$ (1952).

45. 52 STAT. 1055 (1938), 21 U.S.C. \$371(a) (1952).

46. See Land O'Lakes Creameries, Inc. v. McNutt, 132 F.2d 653 (8th Cir. 1943) (standing may be based in part on unfairness of competition); Reade v. Ewing, 205 F.2d 630 (2d Cir. 1953) (manufacturer's standing upheld on allegations of consumer interest). The Reade rule offers competitors an alternate basis of standing under the Federal Food, Drug and Cosmetic Act as consumers; however, the rule has not been used since its formulation.

47. United States Cane Sugar Refiners' Ass'n v. McNutt, 138 F.2d 116, 120 (2d Cir. 1943) (dictum). 
which he had been operating prior to his exclusion. The immediate effect of such action is, of course, positive harm to the excluded supplier, but his removal probably redounds to the benefit of manufacturers of competing substitutes who will fill the void. Unlike the previous situation in which a new competitor was certified, here the administrative agency is not necessarily concerned with the effect of its action on the competitive relationship. For example, the exclusion of the supplier might be based entirely upon a finding that his selling is inconsistent with the public interest.

A. E. Staley Mfg. Co. v. Secretary of Agriculture ${ }^{48}$ is illustrative of the excluded supplier cases. A manufacturer of corn syrup appealed a regulation of the Secretary which established a definition and standard of identity for sweetened condensed milk. The rule, which allowed the use of other sweeteners, did not authorize the use of corn syrup. Therefore, canners of milk sold in interstate commerce would no longer buy from appellant. Similarly, in National Coal Ass'n v. FPC, 49 an FPC order authorizing construction of natural gas pipe lines to service the atomic energy plant at Oak Ridge, Tennessee was appealed by representatives of the coal producers who had been supplying fuel to the government project and who now would lose a substantial volume of business. In both cases standing was sustained.

Decisions upholding standing in this factual situation seem justifiable. Although the litigant may have the opportunity to sell his goods elsewhere, he has been injured by the dislocation following a considerable loss of existing business. Therefore, he has the requisite adverse interest and will diligently prosecute his appeal. The desirability of recognizing supplier's standing is reinforced by the small likelihood that others will be sufficiently interested to appeal this administrative action. Standing probably will be upheld consistently on similar facts ${ }^{50}$ since the close nexus between the administrative action and the injury can be recognized even by courts which purport to decide cases solely by considering the immediacy of appellant's injury.

Not every enterprise which loses a customer or group of customers may be allowed to appeal the administrative action that caused the loss. In the type of case discussed above, the administrative action was directed toward the supplier's customers. But, exclusion-from-market injury can ricochet. Thus, where this supplier loses one customer, he in turn may stop buying from his supplier. This chain reaction effect could be quite widespread so that the number of persons, each of whom has lost a market, could become very large although only one administrative rule is involved.51

48. 120 F.2d 258 (7th Cir. 1941).

49. 191 F.2d 462 (D.C. Cir. 1951).

50. See Atlas Powder Co. v. Ewing, 201 F.2d 347 (3d Cir. 1952), cert. denied, 345 U.S. 923 (1953) (by implication, standing upheld on facts similar to Staley). Cf. Ex-Cell-O Corp. v. Chicago, 115 F.2d 627 (7th Cir. 1940) (standing denied excluded supplier in the absence of an aggrieved person provision).

51. In National Coal, appellants also included representatives of the railroads carrying the coal to Oak Ridge and mine employees. 
Courts often employ the rubric of "indirect" injury to justify a decision denying standing to most of these potential litigants. More than likely the interests of persons more remote from the initial impact of the agency action will be adequately represented by other appellants. In terms of policies which seem to influence the standing result, ${ }^{52}$ the real problem presented by appeals of secondary suppliers and competitors is whether there will be sufficient gain in terms of effective policing of the agency to warrant the extension of standing to additional interests. ${ }^{53}$

\section{Removal of a Competitor's Restriction or Grant of a Benefit}

A third basic situation in which administrative action disrupts a competitive relationship occurs when the agency removes a restriction which had theretofore hampered one competing with the appellant or bestows some benefit on the competitor which enables him to compete more effectively. The injury on which the litigant asserts standing is the actual or prospective loss of business resultant from this administrative action.

Such cases rarely have arisen under an "aggrieved person" statute so the factual situations can be best illustrated by two "legal injury" cases. The first was Hines $v$. United States ${ }^{54}$ which involved a decree that lumber jobbers could store lumber in railroad cars without paying a penalty rate that had been levied prior to the order. This was appealed by some lumber manufacturers who had their own storage facilities and did not stand to gain by the change which benefited their competitors, who lacked such facilities. In the second, Alexander Sprunt \& Son, Inc., $v$. United States, ${ }^{55}$ certain New Orleans shippers attempted to contest the eradication of rail rates which had been favorable to them and discriminatory against interior shippers. ${ }^{56}$ In both cases standing was denied.

One of the few cases ${ }^{37}$ under an "aggrieved person" provision involving the removal of a restriction on the litigant's competitor, United States Cane Sugar Refiners' Ass'n v. $M c N u t t$, 58 indicates that a primary obstacle to standing under these facts may be the problem of establishing that injury actually will result from removal of the restriction on the competitor. That case centered about a regulation under the Federal Food, Drug and Cosmetic Act by which fruit canners utilizing dextrose and corn sugar no longer were required to indicate on the product's label that these ingredients

52. See text at pp. 845-47 supra.

53. See L. Singer \& Sons v. Union Pac. R.R., 311 U.S. 295 (1940) ; Clarksburg Publishing Co. v. FPC, 225 F.2d 511 (D.C. Cir. 1955); National Coal Ass'n v. FPC, 191 F.2d 462 (D.C. Cir. 1951).

54. 263 U.S. 143 (1923).

55. 281 U.S. 249 (1930).

56. Inasmuch as appellant had not exhausted his administrative remedy with respect to the application of the new rate to him, the Court limited the issue on appeal to whether appellant had standing to contest the eradication of the discriminatory features of the old rate.

57. See Eastern Airlines, Inc. v. CAB, 185 F.2d 426 (D.C. Cir. 1950); United States Cane Sugar Refiners' Ass'n v. McNutt, 138 F.2d 116 (2d Cir. 1943); Land O'Lakes Creameries, Inc. v. McNutt, 132 F.2d 653 (8th Cir. 1943).

58. 138 F.2d 116 (2d Cir. 1943). 
had been used. Appellants contended that canners now would increase their purchases of these lower priced sugars and decrease their use of cane sugar. Standing was denied. The court based its holding upon the fact that appellants' injury was speculative inasmuch as they had shown no public sales resistance to products using corn and dextrose sugars where their presence was indicated on the label.59

This case illustrates the practical difficulty of proving sufficient injury to meet the requirement of aggrievement. Nevertheless, cases meeting this requirement conceivably could arise under "aggrieved person" provisions, ${ }^{60}$ especially under statutes like the Federal Food, Drug and Cosmetic Act which apply such provisions to the review of administrative rules. ${ }^{61}$ The courts may sustain the competitor's standing by analogizing to cases where a new competitor is launched. In a sense, the administrative launching of the new enterprise is similar to the removal of a restriction or prohibition that had prevented previous operation. However, the critical issue in these cases is likely to be whether other appellants are better suited to represent the public interest than this appellant would be.

Where grant of a benefit to a competitor, rather than removal of a restriction, is involved, there is again the initial problem whether or not the appellant has been injured. One case seems to have avoided this question by sustaining standing to challenge the validity of the grant of a federal subsidy solely on the basis of a general allegation of a competitive relationship. ${ }^{62}$ Since judicial interpretation of the "case" or "controversy" provisions requires some showing of adverse effect, it would have been preferable for the court to have articulated what detriment the appellant suffered. However, where the grant of a federal subsidy, such as air mail pay, ${ }^{63}$ is subject to an "aggrieved person" appeal, it might be necessary to minimize the requirement of substantial injury to assure some judicial review. While the Postmaster General has standing to appeal CAB mail pay determinations ${ }^{\beta 4}$ he might do so only infrequently, as where novel questions of law are presented. ${ }^{65}$ The recipient's competitor may be the only person likely

59. Id. at 121 .

60. See cases cited in note 57 supra.

61. Although this situation might arise where conditions in an agency order, such as a certificate of public convenience and necessity, were suspended, it seems more likely to occur where the agency changes rules which previously operated to the disadvantage of appellant's competitor. However, some "aggrieved person" provisions only apply to the review of administrative orders, not rules. See, e.g., Natural Gas Act, 52 Stat. 831 (1938), 15 U.S.C. 8717 (b) (1952), United Gas Pipe Line Co. v. FPC, 181 F.2d 796 (D.C. Cir.), cert. denied, 340 U.S. 827 (1950).

62. American President Lines, Ltd. v. Federal Maritime Bd., 112 F. Supp. 346 (D.D.C. 1953) (no discussion of adverse effect; court merely speaks of competitor status). Actually, this case merely suggests what a court faced with the problem under an "aggrieved person" provision might do. The case itself turns on a questionable construction of section 10(a) of the Administrative Procedure Act. See text following note 101 infra.

63. Civil Aeronautics Act of 1938, 52 Stat. 998, 1024, 49 U.S.C. $\S \S 486($ a), 646(a) (1952).

64. Western Air Lines, Inc. v. CAB, 347 U.S. 67 (1954).

65. Ibid. 
to police the Board regularly, challenge favoritism, or present facts militating against the recipient's claims. Indeed, the competitor may have fuller knowledge of such matters than the Post Office Department. However, appellant's difficulty in establishing that he has been injured by action benefiting his competitor partially may explain the paucity of cases in this area. ${ }^{66}$

\section{Who Is the Appellant?}

The determination of the standing issue may depend not only on the manner in which the injury arose but, under some statutes, may turn upon the identity of the appellant. For example, where a statute has been passed to protect a certain class of persons, the identity of an appellant as. a member of that class is fair assurance of standing to appeal.67 This issue of identity becomes especially important in two factual situations: when the appellant is not a member of the industry regulated by the agency whose action is in question, and when the appellant is a representative trade association.

\section{Appellants Who Are Not Members of the Industry}

A leading case dealing with the problem of the standing of an outsider to challenge administrative action is $L$. Singer \& Sons $v$. Union Pac. $R . R .{ }^{68}$ There standing to enjoin ${ }^{69}$ rail extension was denied because the plaintiff was not a member of the transportation industry. Plaintiffs were produce merchants and city officials connected with a municipal market which served a large surrounding territory. The rail extension in issue was intended to provide transportation facilities for a proposed competitive market. A majority of the Supreme Court affirmed dismissal of plaintiffs' suit on the ground that plaintiffs failed to show a "special and peculiar interest" in the transportation situation and that their interest merely was in the status of market competition as affected by the rail extension. This opinion emphasized that the purpose of the Interstate Commerce Act is to promote the public interest in transportation through maintenance of the vitality of the member units. Injury to market competitors reflects no immediate danger to the transportation system. ${ }^{70}$

66. For a discussion of standing problems in subsidy cases, see Eisenberg, supra note 12.

67. See, e.g., Reade v. Ewing, 205 F.2d 630 (2d Cir. 1953), and cases cited in note 38 sipra.

68. 311 U.S. 295 (1940).

69. While the case involved standing to enjoin an uncertified rail extension, courts applying $\S 1(20)$ of the ICA have reached similar results in cases of standing to sue and standing to appeal. Compare cases cited in note 38 supra, with ClaiborneAnnapolis Ferry Co. v. United States, 285 U.S. 382 (1932).

70. The dissent asserts that an important factor considered by the Commission is the effect of rail extension on market competition. 311 U.S. at 312 . The cases which it cites indicate that the Commission has not given this factor the weight which the dissent claims. See, e.g., Western Pac. Calif. R.R., 162 I.C.C. 5 (1930); Minnesota Western R.R., 111 I.C.C. 377 (1926). 
A concurring opinion of five Justices expressed an unwillingness to involve the courts in the task of determining the standing of the numerous private interests who might be affected by rail extension unless there was an express congressional mandate. ${ }^{71}$ The opinion reasoned that since the act expressly granted the ICC and state agencies, as well as any "party in interest," standing to sue, the meaning of "party in interest" should be restrictively interpreted to compel most private concerns to seek redress through the administrative bodies, who would amply protect their interest.

This consideration of adequate protection by other litigants is also relevant under other statutes to determine the standing of non-members of the industry who attempt to contest certification, since existing members usually will be able to challenge the agency decision. ${ }^{22}$ However, the Court of Appeals for the District of Columbia recently upheld the standing of oil barge operators to challenge an order authorizing a gas pipe line to convert and carry petroleum into the market served by appellants. ${ }^{73}$ The court distinguished Singer because the applicable statute in this case provides no special scheme for official challenge of administrative error. ${ }^{74}$ The decision would remain unreviewed unless appellant could appeal since existing members of the natural gas industry would certainly not contest the order.

In Clarksburg Publishing Co. v. FCC, , t5 the standing of a newspaper to appeal the grant of a television station license was upheld without discussion. If the considerations favoring some restriction of the number of litigants are sound, this result is questionable since existing radio and television licensees are potential appellants. ${ }^{76}$ However, in some situations, it might be useful to allow newspapers to appeal a grant of a television license. The applicant may be controlled by interests which also control most of the other communications media in the area. ${ }^{77}$ Or, though com-

71. 311 U.S. at 305 . Four Justices concurred both in the opinion of the Court and in the separate concurring opinion.

72. See text at pp. 846-47 supra.

73. Pittsburgh v. FPC, 24 U.S.L. WeEk 2418 (D.C. Cir. March 8, 1956).

74. Pittsburgh v. FPC, supra note 73, at 2419. The provision for judicial review merely grants standing to an "aggrieved party." Natural Gas Act, 55 STAT. 831 (1938), 15 U.S.C. \& $717 \mathrm{r}$ (b) (1952). This class does not seem to include official bodies since the preceding subsection specifies that certain officials and "aggrieved parties" may petition the FPC for a rehearing. Natural Gas Act, 52 STAT. 831 (1938), 15 U.S.C. $\$ 717 \mathrm{r}(\mathrm{a})$ (1952).

75. 225 F.2d 511 (D.C. Cir. 1955). See, generally, 102 U. PA. L. Rev. 1080 (1954) (discussing an FCC decision in this case).

76. Cf. Salinas Broadcasting Corp., 3 PIKE \& Fischer Ad. L. DEc. (2d ser.) 369 (FCC 1953) (existing television station); Versluis Radio and Television, Inc., 3 PIKe \& Fischer AD. L. DeC. (2d ser.) 365 (FCC 1953) (radio station). Both cases involve standing to protest the grant of a license without a hearing. See note 79 infra. Although standing before an agency may be based on different considerations than standing to appeal, Davis, supra note 16, at 381-86, the criteria supposedly are the same under the Federal Communications Act. See Metropolitan Television Co. v. United States, 221 F.2d 879, 880-81 (D.C. Cir. 1955); Note, Standing To Protest Before the FCC, 55 ConUM. I. REv. 209, 211-12 (1955).

77. This was alleged to be the situation in Clarksburg. 225 F.2d at 515-16, 518-19. This factor may be taken into consideration in determining whether grant of the license application will be in the public interest. Id. at 519. 
petitors exist, they may forebear from challenging the application in return for a similar future favor. ${ }^{78}$ In either case, a license might be granted to an undesirable applicant without challenge by members of the industry. ${ }^{79}$ The advisability of the Clarksburg result, therefore, depends on whether its usefulness in this special circumstance will be outweighed by the inconvenience of unmeritorious or unnecessary ${ }^{80}$ newspaper appeals. ${ }^{81}$

A somewhat analogous situation may arise under the Federal Food, Drug and Cosmetic Act where a supplier of an ingredient may have standing to appeal a change in the standards of a product's identity or quality. Practically, suppliers may be the only group likely to raise the question in the courts; manufacturers of the standardized product are not likely to appeal if there is little difference in cost between this ingredient and its substitutes. The small likelihood of consumer appeal has been noted. Furthermore, even if the theories for limiting the number of litigants are valid, the class of prospective appellants here involved is small.

\section{Trade Associations}

The trade association is the second type of litigant whose standing may be questioned on the ground it is not the proper plaintiff or appellant. However, the issue has arisen infrequently and, when it has, courts have generally determined the issue as if the appellant were the individual affected enterprise. For example, in National Coal, ${ }^{82}$ the standing of the

78. Cf. id. at 519-20 (allegations that Clarksburg bought off a competitive applicant).

79. To expedite the establishment of television service and clear up a large number of pending applications (FCC ANN. REP. 93 (1953)), the FCC has utilized its statutory powers to grant a license without a hearing. Federal Communications Act, 66 Srar. 715, 47 U.S.C. §309(a) (1952); 47 C.F.R. \&1.382 (1953). Therefore, certain private persons, by protest, may call the FCC's attention to facts which show the issuance of a license not to be in the public interest. See, generally, Note, 55 Colum. L. Rev. 209 (1955) ; 102 U. PA. L. Rev. 1080 (1954).

80. Cf. FCC ANs. Rep. 93 (1954) (protests made unnecessarily and to prevent competition); Note, 55 ColuM. L. REv. 209, 223 (1955).

81. Similarly under other statutes, where the outsider is a member of a different segment of the same industry, such an appellant may have standing-for one of several reasons. Because of the public interest in the vitality of both modes of transportation, railroads have standing to appeal injurious Commission action which concerns motor carriers, Alton R.R. v. United States, 315 U.S. 15 (1942), even though competing motor carriers also may have standing. See note 39 supra. Moreover, appeal from the other portion is desirable if the objection to the administrative action is based on unfair favoritism of one segment at the other's expense. For these reasons, it seems likely that motor carriers would have standing in the reverse situation. For different reasons, natural gas pipe line certification is subject to appeal by coal producers. See text at note 49 supra. Their standing may furnish appeals to test the validity of certification where, because there is no existing gas carrier in the area, ibid., or the existing carrier has commitments for his full capacity, see text at note 32 supra, there is no eligible challenger in the ranks of the natural gas industry. Furthermore, producers of competing fuels have some interest in this matter since Congress indicated that the possible effect on such interests should be considered in the certification proceeding. H.R. REP. No. 1290, 77th Cong., 1st Sess. 3 (1941); National Coal Ass'n v. FPC, 191 F.2d 462, 465 (1951).

82. See text at note 49 supra. See also United States Cane Sugar Refiners' Ass'n v. McNutt, 138 F.2d 116 (2d Cir. 1943) ; Associated Industries, Inc. v. Ickes, 134 F.2d 694 (2d Cir.), dismissed as moot, 320 U.S. 707 (1943); cf. Land O'Lakes Creameries, Inc. v. McNutt, 132 F.2d 653 (8th Cir. 1943). 
coal producers who were represented by their trade association was upheld. Federal courts have avoided the conceptual objection that the association has no interest in the dispute. ${ }^{83}$ In practice, many trade associations are active proponents of their members' interests in desired legislation. They may act as a liaison between the agency and regulated industry. Thus they will have an adversary interest in matters adversely affecting the industry. Furthermore, one possible result of denying standing to the association might be that the association's counsel merely would conduct the appeals in the names of particular members. ${ }^{84}$ However, these considerations, which would tend to support allowing the association to challenge administrative action in behalf of its members, may be overbalanced by the possible tendency of the association to act in the interests of its members in blocking additional competition. The association may challenge certification of new competitors as a matter of course. Such perfunctory action may result merely in obstructing or delaying the entrance of the new business without any corresponding gain to the public interest in the correction of administrative error. ${ }^{85}$

\section{The Effect of the Administrative Procedure Act on the Prior Law of Standing}

Although enactment of comprehensive legisiation covering administrative procedure could have considerably clarified the law of standing, two major issues still remain unresolved under the APA. ${ }^{80}$ There is doubt as to whether the more liberal statutory standing rules have been extended to encompass all administrative action or cover only action by those agencies previously subject to "aggrieved person" appeal. Secondly, there still has been no definitive determination whether the act permits standing whenever the litigant has in fact incurred some detriment because of administrative action.

The uncertainty stems from the ambiguous language of section 10 (a). The section provides:

"Any person suffering legal wrong because of any agency action, or adversely affected or aggrieved by such action within the meaning of any relevant statute, shall be entitled to judicial review thereof." ${ }^{87}$

83. For an example of such conceptualism, see Penn-Harris Hotel Co. v. Pennsylvania Pub. Util. Comm'n, 166 Pa. Super. 394, 71 A.2d 853 (1950).

84. See Atchison, T. \& S.F. Ry. v. United States, 130 F. Supp. 76 (E.D. Mo.), aff'd per curian, 350 U.S. 892 (1955) (appellants actually were represented by counsel for the Association of Western Railways).

85. See Byse, Opportunity To Be Heard in License Issuance, 101 U. PA. L. REV. 57, 96-99 (1952), for a review of the standing of trade associations of liquor licencees to participate in the administrative hearing. The author suggests that neither existing licencees nor their trade associations should have standing.

86. 60 Stat. 237 (1946), 5 U.S.C. \$\$1001-11 (1952).

87. 60 STAT. 243 (1946), 5 U.S.C. $\$ 1009$ (a) (1952). 
Several interpretations are possible. The section may merely codify existing law with respect to standing. This would require reading the qualifying clause "within the meaning of any relevant statute" as modifying both "adversely affected" and "aggrieved." It is also possible to construe the language as enlarging the scope of "aggrieved person" appeal by applying the criteria of adverse effect developed prior to the APA to all appeals reviewable under the APA. Under this interpretation, the qualifying phrase would modify only "aggrieved," not "adversely affected." The third possibility is that the APA grants standing to anyone in fact adversely affected. This requires the same language construction as the second interpretation, but would remove the "indirect injury" limitation formerly associated with the use of "aggrieved" or "adversely affected," and anyone proving detriment could appeal the administrative action which produced it.8s

In order to select any of these possibilities as the correct one, one of the primary issues which must be resolved is whether the phrase "within the meaning of any relevant statute" qualifies "adversely affected" as well as "aggrieved." If the qualification only were intended to modify "aggrieved," it would have been preferable to place a comma after "adversely affected." More important, however, if section 10 (a) itself grants standing to persons adversely affected, certain phrases in the section are practically surplusage. It seems quite improbable that one could suffer "legal wrong" 89 but not be adversely affected. Yet section 10 (a) begins by mentioning those who suffer such "legal wrong." Similarly, it would have been unnecessary to further provide standing for persons "aggrieved . . . within the meaning of any relevant statute." 90 Such a construction is unlikely in the absence of a strong basis in legislative history.

88. A fourth possible interpretation is that the phrase "within the meaning of any relevant statute" modifies both "adversely affected" and "aggrieved," but that a "relevant statute" need not be the particular one under which the agency acted. Thus a competitor challenging action taken under the Maritime Act could justify his standing on the basis of competitor cases under the Communications Act. (Such a reading of the section may underly the result in American President Lines, Ltd. v. Federal Maritime Bd., 112 F. Supp. 346 (D.D.C. 1953), discussed in text at note 102 infra.) However, this interpretation not only is unsupported by legislative history but also seems a vague and circuitous way to extend statutory standing. Furthermore, the effect of this interpretation might be to render the "legal wrong" provision superfiuous.

89. Both Committee reports and the debates contain confused explanations of the meaning of "legal wrong." S. REP. No. 752, 79th Cong., 1st Sess. 128, 192 (1945); 92 Cong. Rec. 2152-53 (1946). However, Senator McCarran's final position seems to have been that this phrase was not intended to change prior law and, therefore, merely was a substitute for "legal injury." 92 id. at 2153 . For an indication of the constitutional problem which would be raised by allowing persons with no personal stake in the outcome to challenge official action simply because it may be illegal, see note 4 supra.

90. With respect to the contention that "adverse effect" under APA means "adverse effect in fact," it should also be noted that it would be extremely poor draftsmanship to use the former phrase, to which a restrictive meaning had been attached, to indicate a removal of the "indirect injury" limitation-especially when Congress could have added the words "in fact." Compare the somewhat different problem of the meaning of "substantial evidence" within APA $\$ 10(\mathrm{e})(\mathrm{B})(5)$ discussed in Universal Camera Corp. v. NLRB, 340 U.S. 474 (1951). 


\section{Congressional History}

Although congressional history of section 10 (a) is not conclusive, it seems to support the view that the provision was intended to enact existing law. In any event, there is no strong evidence that Congress meant to change the prior law of standing.

Earlier bills from which the APA finally derived provided:

"Any person adversely affected by any agency action shall be entitled to judicial review thereof in accordance with this section." 91

Here a change in prior law clearly was expressed. Moreover, the form of the provision indicates a realization that, if the APA grants standing based on adverse effect, it is surplusage to provide for the continuance of prior statutory or "legal wrong" standing.

After the Senate Committee conferred with private groups, representatives of the Attorney General and the agencies, ${ }^{92}$ section 10(a) was completely rewritten to read:

"Any person suffering legal wrong because of any agency action shall be entitled to judicial review." 23

This second version clearly rejects the initial attempt to change prior law. The section was revised in committee once more, ${ }^{94}$ and the result was the present text of section $10(\mathrm{a}) .95$ In view of this development of the section, the crucial phrase "adversely affected or aggrieved... within the meaning of any relevant statute" which appears in the final draft merely seems designed to complete the codification of existing law which the second draft began.

However, the following statement relating to the final revision appears in both committee reports:

91. S. 7, 79th Cong., 1st Sess. $\$ 10$ (1945) (McCarran Bill); H.R. 1203, 79th Cong., 1st Sess. $\$ 10$ (1945) (Sumners Bill) ; see H.R. Rep. No. 1980, 79th Cong., $2 d$ Sess. 14 (1946). A similar provision for standing appeared in several of the other bills. H.R. 339, 79th Cong., 1st Sess. \$ 9 (1945); H.R. 1117, 79th Cong., 1st Sess. $\$ 9$ (1945); H.R. 2602, 79th Cong., 1st Sess. \$4 (1945).

92. H.R. REp. No. 1980, 79th Cong., 2d Sess. 14 (1946). The House Committee was in contact with the Senate Committee during this period and participated in the bill's development. Id. at 15. The Senate Committee also drew on the House hearings. S. Doc. No. 248, 79th Cong., 2d Sess. 11 (1946).

93. Id. at 36; H.R. REP. No. 1980, 79th Cong., 2d Sess. 14 (1946).

94. Ibid.

95. This result was introduced as revised S. 7 in the Senate and passed on March 12, 1946. 92 Cong. Rec. 2167 (1946). Revised S. 7 was introduced in the House as H.R. 4941 (Sumners Bill). However, the House Committee had suggested some further clarifications, which did not affect $\S 10(a)$. These changes were introduced in a companion bill, H.R. 5988 (Walters Bill). H.R. REP. No. 1980, 79th Cong., 2d Sess. 16 (1946). The House passed H.R. 5988 on May 24, 1946. 92 CoNG. REc. 5668 (1946). The Senate adopted this version on May 7. 92 id. at 5791. 
"This subsection confers a right of review upon any person adversely affected in fact by agency action or aggrieved within the meaning of any statute." 98

The statement indicates that the final draft of the section rejected the narrow legal injury standing of the second draft, and forms the primary support for the theory that Congress intended to change prior standing law and adopted "adverse effect in fact" as a basis of standing under the APA itself.

However, the authority of the committee statement is uncertain in light of other portions of the legislative history. In both committee reports, the statement was introduced with a synopsis of section 10(a) which reads:

"Any person suffering legal wrong because of any agency action, or adversely affected within the meaning of any statute, is entitled to judicial review." 97

Since this condensation directly relates the qualifying phrase "within the meaning of any statute" to the term "adversely affected," and makes no mention of "in fact," it does not support the indication of the statement that there was a change in law.

Additional weight can be given to the synopsis because it was directly quoted by the bill's sponsors during the congressional debates to explain the operation of the section. ${ }^{98}$ Conversely, no reference was made to the comment. Furthermore, all other references to section 10 (a) during the debates indicated a view that it merely codified prior law. Both a sponsor and a committee member quoted, with apparent approval, the Attorney General's statement, "This reflects existing law." ${ }^{99}$ The same committee member cited a Department of Justice memorandum to the same effect. ${ }^{100}$ It should also be noted that most of these statements by the bill's sponsors or committee members were made in prepared statements rather than extemporaneously in the course of debate. Clearly, the sponsors and draftsmen of the statute did not interpret this section as granting standing based either on adverse effect without reference to the relevant statute or adverse effect in fact to the review of all agency action. Thus, since the main course of legislative history indicates that section 10 (a) simply codified prior law and the interpretation necessary to justify a change of prior law deprives other portions of the section of any real effect, it seems unjus-

96. S. REP. No. 752, 79th Cong., 1st Sess. 26 (1945) ; H.R. REP. No. 1980, 79th Cong., $2 d$ Sess. 42 (1946). (Emphasis added.)

97. Ibid.

98. 92 Cong. REc. 2158 (1946) (Senator McCarran); 92 id. at 5654 (Representative Walters).

99.92 id. at 2153 (Senator McCarran); 92 id. at 2984-85 (Representative Hobbs).

100. 92 id. at 2988 (Representative Hobbs). 
tified to base an important change of law chiefly on a single committee statement made in ambiguous context. ${ }^{101}$

\section{Judicial Interpretation}

Such judicial authority as now exists supports the view that section 10(a) did not change prior law. However, strong authority for either position is lacking since only one of the cases provides any discussion of the problem.

The district court for the District of Columbia was the first to interpret section 10(a), in American President Lines, Ltd. v. Federal Maritime $B d .^{102}$ Plaintiff sought to set aside the grant of a subsidy to a competitor. No legal injury was involved, and the relevant statute contained no "aggrieved person" provision. Nevertheless, standing was upheld. The court apparently disregarded the qualification "within . . . any relevant statute," and held plaintiff to be aggrieved, citing as authority cases arising under the "aggrieved person" provision of the Federal Communications Act. This interpretation is most consistent with the second possible construction previously discussed. The same court through a different judge attempted to tie this view more firmly to statutory language in Atchison, T. \& S. F. Ry. v. Summerfield. ${ }^{103}$ The court construed the phrase "within . . . any relevant statute" to modify "such [agency] action." No explanation of this view was given. The holding is unjustified by any legislative history; furthermore, under this interpretation the APA does not expressly provide review of administrative action taken without pretense of authority or under color of an irrelevant statute. Shortly thereafter, the District's Court of Appeals, in Kansas City Power \& Light Co. v. $M c K a y,{ }^{104}$ held that section $10(a)$ did not alter prior law. Relying

101. It may be that this otherwise inexplicable comment was not intended to convey the meaning it appears to suggest. "Within the meaning of any relevant statute" can be read to qualify both "adversely affected in fact by agency action" and "aggrieved." This reading would bring the comment more nearly into line with the synopsis which introduces it. Furthermore, the balance of the Senate comment seeks to explain "legal wrong" as follows:

“. . . [T] The phrase 'legal wrong' means such a wrong as is specified in subsection (e) of this section. It means that something more than mere adverse personal effect must be shown-that is, that the adverse effect must be an illegal effect. The law so made relevant is not just constitutional law but any and all applicable law." S. REP. No. 752, 79th Cong., 1st Sess. 26 (1945). (Emphasis added.)

Therefore, as a whole, the comment not only discusses two different theories of standing, but also attempts to distinguish them by comparison with a single standard, "adverse effect." "Legal wrong" standing requires a detriment which is "illegal"; statutory standing merely requires detriment. See also H.R. REP. No. 1980, 79th Cong., $2 d$ Sess. 42 (1946) ; 92 CoNG. Rec. 2152-53 (1946) (Senate debate). Read in context, therefore, the phrase "in fact" seems less emphatic, and it seems more likely that it was used in the first sentence only to anticipate the confused distinction which follows.

102. 112 F. Supp. 346 (D.D.C. 1953) (Holtzoff, J.); see note 88 supra.

103. 128 F. Supp. 266 (D.D.C. 1955) (Kirkland, J.).

104. 225 F.2d 924 (D.C. Cir.), cert. denied, 350 U.S. 884 (1955). 
chiefly on the Attorney General's comment, ${ }^{105}$ the court expressly rejected the American President Line interpretation. ${ }^{108}$ The same result was reached without discussion in another district. 107

Since legislative history, the most reasonable construction of the language of section $10(a)$ and the few decided cases support the conclusion that the APA merely codifies prior law, it is most likely that future cases applying the section will hold that standing to appeal administrative decisions will be determined either under the judicial "legal injury" standard or, where relevant, under a statutory "aggrieved person" provision including the embelishments added by case law under the "indirect injury" limitation.

\section{Commentary}

Presently, the most basic issue with respect to statutory standing is the validity of the fundamental policy assumptions which lead the courts to interpret the "aggrieved person" provisions restrictively. While competitor cases represent only one segment of the law of standing, they indicate some of the considerations to be taken into account.

Although statutes normally provide that suit or appeal alone will not operate to stay the effect of an administrative decision, ${ }^{108}$ actually judicial review may prevent a decision from being put into practical effect until its validity is finally upheld in the courts. For example, entry or expansion into one of the regulated industries which requires a large monetary outlay is not likely to be undertaken if the agency certification is being challenged. ${ }^{109}$. However, the significance of this factor will vary with the type of agency regulation and the expense involved in effectuating the agency decision. A decision of the Food and Drug Administrator that a particular ingredient should not be used in the manufacture of a product can be put into effect immediately, subject to revocation if the reviewing court reverses the Administrator.

Where judicial review will delay the effect of the administrative decision, there is a danger that competitors may resort to review merely to take advantage of this result. Although the expense involved in challenging such orders will check unfounded resort to the courts to some extent, it is conceivable in some cases that the litigant will believe a temporary relief from competition overbalances the costs of suit. ${ }^{110}$

105. Id. at 932 ; see text at note 99 supro.

106. 225 F.2d at 932 .

107. Atchison, T. \& S.F. Ry. v. United States, 130 F. Supp. 76 (E.D. Mo.), aff'd on other grounds per ctriam, 350 U.S. 892 (1955) (alternative holding).

108. E.g., Securities Act of 1933, 48 STAT. 81, 15 U.S.C. $\$ 77$ (b) (a) (1952); Federal Power Act, 49 STAT. 861 (1935), 16 U.S.C. § 825l(c) (1952).

109. See note 22 supra.

110. Cf. FCC ANs. ReP. 93 (1954). 
Another objection occasionally interposed to a liberal application of standing provisions is that it would result in a flood of appeals to the courts which would hamper effective administration. ${ }^{111}$ However, the logic of this position is highly questionable. ${ }^{112}$ First, the expense of litigation will always operate as some deterrent, especially when the prospective litigant's position is being represented by another recognized challenger. Second, existing statutes specify short periods of time within which appeals must be taken. ${ }^{113}$ Thus, separate suits before the same court could be consolidated. Other procedural devices further minimize the possibility that a great number of separate cases simultaneously will be testing the validity of the same administrative act.114 However, even if there were some validity in the belief that the number of suits challenging administration would increase, it does not follow that the result would be increased ineffectiveness on the administrative level, since the preparation required to meet court challenge is usually handled by the legal staff rather than the administrative officials themselves.

The imposition of more liberal statutory standing would always be subject to some limitation since the courts have interpreted the constitutional "case" or "controversy" provision to require a showing of adverse effect. 115 Beyond this point, however, arguments against extending statutory standing must depend either on the belief that only litigants who meet stricter standards of adversity are likely to undertake the most effective and full presentation of the issues and thereby provide the best protection of the public interest in rectifying administrative error, or on the conviction that the delay in the effectiveness of the decision that will result will greatly impede the public need for expeditious and final administrative disposal of public business. The competitor cases suggest that in many instances statutory standing could be granted without disturbing the functioning of the administrative process. Expansion of the standing rules is possible even if the APA is determined to have codified prior law, as suggested. Much of the prior case law involves the courts' interpreta-

111. See United States Cane Sugar Refiners' Ass'n v. McNutt, 138 F.2d 116, 120 (2d Cir. 1943).

112. See Associated Industries, Inc. v. Ickes, 134 F.2d 694 (2d Cir.), dismissed as moot, 320 U.S. 707 (1943).

113. E.g. Natural Gas Act, 52 Stat. 831 (1938), 15 U.S.C. §717r(a) · (1952) (30 days); Federal Food, Drug and Cosmetic Act, 52 STAT. 1055 (1938), 21 U.S.C. $\S 371(f)(1)$ (1952) (90 days).

114. Consolidation of separate appeals further is facilitated under those statutes which provide that agency action is reviewable only in the Circuit Court for the District of Columbia. E.g., Federal Power Act, 49 STAT. 860 (1935), 16 U.S.C. $\$ 825 l$ (b) (1952) ; Federal Communications Act, 66 STAT. 718 (1952), 47 U.S.C. $\$ 402$ (b) (1952). Other statutes may provide that the circuit court in which a petition for appeal and a transcript of the record are first filed shail have exclusive jurisdiction to review the particular order. E.g., Securities Act of 1933, 48 STAT. 80,15 U.S.C. $\$ 77 i(a)$ (1952); Natural Gas Act, 52 STAT. 832 (1938), 15 U.S.C. $\$ 717$ r (b) (1952). Even where such provisions are not applicable, it is possible for courts in which later suits or appeals are filed to stay the case pending a decision by the court in which the first suit or appeal was begun.

115. See note 20 supra. 
tions of the statutory provisions. Judicial re-examination of the assumptions behind restrictive application of standing could result in a realization that the balance of the public need against the public inconvenience warrants a more liberal standing policy in many cases. ${ }^{116}$

116. For the view that standing based on "adverse effect in fact" should be applicable to the review of all federal administrative action, see Davis, supra note 16, at 367. The Administrative Code proposed by the Task Force of the Hoover Commission granted a right of review to all persons adversely affected or aggrieved. U.S. Commission on Organization of the Executrve Branch of the Government, Task Force Report in Legal Services AND Procedure 373, 414 (1955). However, this recommendation was not adopted in the final report. U.S. Commission on Organization of the Executtue Branch of the Government, Final Report in Legal Services and Procedure 75-76 (1955). 